\title{
UMA CRÔNICA DE RETORNO DA COMPANHIA DE JESUS NO SÉCULO XIX: AÇÃO MISSIONÁRIA E PERSISTÊNCIA CATEQUÉTICA JUNTO AOS ÍNDIOS DO BRASIL
}

\author{
Maria Juraci Maia Cavalcante*
}

\section{RESUMO}

Trata da crônica missionária e do retorno dos Jesuítas ao Brasil, no século XIX, quando os inacianos retomam a sua narrativa histórica. Tem apoio em Vitorino Nemésio (1971), Jorge Couto (1995), Luce Giard (2012) e Michael de Certeau (2012), na análise de discursos e fontes. Destaca que, entre 1841 e 1873, há o propósito de retomada das missões junto aos indígenas e a criação de diversas escolas, período em que ainda prevalece contra a Companhia de Jesus a suspeita posta pelo ideário pombalino.

Palavras-chave: missão, jesuítas, educação.

* Universidade Federal do Ceará (UFC), Fortaleza/CE, Brasil. 


\section{UNA CRÓNICA DE RETORNO DE LA COMPANIA DE JESÚS EM EL SIGLO XIX: ACCÍON MISIONERA Y PERSISTENCIA CATÉCHIQUE COM LOS ÍNDIOS DE BRASIL}

\section{RESUMEN}

Se trata de la crónica misionera y del regreso de los jesuitas a Brasil en el siglo XIX, cuando los ignacianos retomaron su narrativa histórica. Tiene apoyo en Vitorino Nemésio (1971), Jorge Couto (1995), Luce Giard (2012) y Michael de Certeau (2012), en el análisis de discursos y fuentes. Destaca que, entre 1841 y 1873 , existe el propósito de retomar las misiones con los indígenas y la creación de varias escuelas, período en el que aún prevalece la sospecha de la ideología de Pombal contra la Compania Jesús.

Palabras clave: misión, jesuitas, educación.

\section{CHRONICLE OF RETURN FROM THE COMPANY OF JESUS IN THE XIX CENTURY: MISSIONARY ACTION AND CATECHETICAL PERSSTENCE WITH THE INDIANS OF BRAZIL}

\section{ABSTRACT}

It deals with the missionary chronicle and the return of the Jesuits to Brazil in the nineteenth century, when the Ignatians resumed their historical narrative. He has support in Vitorino Nemésio (1971), Jorge Couto (1995), Luce Giard (2012) and Michael de Certeau (2012) in the analysis of discourses and sources. He emphasizes that, between 1841 and 1873 , there is the purpose of resumption of missions with the indigenous people and the creation of several schools, a period in which the suspicion still posed by Pombal's ideas still prevails against the Company of Jesus.

Keywords: mission, jesuits, education.

\section{UNE CHRONIQUE DU RETOUR DE LA COMPAGNIE DE JESÚS À EL SIGLO XIX: ACCÍON MISIONERA ET PERSISTANCE CATÉCHIQUE AVEC LOS ÍNDIOS DE BRÉSIL}

\section{RÉSUMÉ}

Il traite de la chronique de la mission et du retour des jésuites au Brésil au XIXe siècle, Iorsque les ignaciens ont repris leur récit historique. Ils on làppui de Vitorino Nemésio (1971), Jorge Couto (1995), Luce Giard (2012) y Michael de Certeau (2012), dans l'analyse des discours et des sources. Il précise qu'entre 1841 et 1873 il y a le but de reprendre les missions avec les indigènes et la création de plusieurs écoles, une période pendant laquelle le soupçon posé par l'ídeologie pombaline prévant encore contre la Compagnie de Jesús.

Mots-clés: missión, jésuites, éducation. 


\section{INTRODUÇÃO}

Em meados dos anos 1920, vem a lume no Rio de Janeiro - pela Imprensa do Annuario do Brasil - Almanak Laemmert, de uma Separata do Annuario Catholico - um relato de natureza histórica que trata das missões jesuítas no Brasil, escrita pelo jesuíta, J. M. de Madureira (1924), a qual hoje repousa na Biblioteca Nacional de Lisboa, onde a consultamos. Seria mais uma crônica jesuítica que poderia passar desapercebida, entre tantos outros registros, não trouxesse ela alusão ao retorno da Companhia de Jesus ao Brasil do século XIX. A maioria dos registros documentais e historiográficos refere-se ao período colonial, que tem seu fecho na expulsão pombalina de 1759 e, mais recentemente, à ação missionária do século XX, feito o Brasil e Portugal já República, temática que tem nos ocupado em particular, nos últimos dez anos, sobretudo em relação ao retorno dos Jesuítas portugueses ao nordeste brasileiro.

Por esta razão, debruço-me aqui sobre o conteúdo do referido relato, sabendo ser ele constituído antes de tudo para uma defesa dos Jesuítas, pois enaltece suas ações missionárias e de suas instituições educativas. Tem, portanto, objetivo justiceiro, conforme poderemos ver mais adiante. Guarda a memória histórica da Companhia, se dirigindo tanto aos seus detratores, quanto aos novos padres que recebem formação jesuítica. Enaltece sobremaneira os Jesuítas listando seus feitos e empenhos.

Sabemos da importância de uma atenção especial para com as fontes recolhidas em nossos propósitos investigativos. Se olharmos com atenção para cada uma delas, teremos a possibilidade de fazer perguntas relevantes de natureza epistemológica e metodológica, que contribuem positivamente para o refinamento do nosso trabalho no campo da História.

No caso em estudo, a sua emergência como texto se dá por uma política deliberada de submeter o passado missionário dos inacianos ao jugo mais rigoroso da cronologia e da reconstituição histórica. Essa tendência demarca no século XX uma nova fase de trabalho narrativo dos Jesuítas, que irá substituindo 
pouco a pouco o empenho meramente descritivo e memorialístico de suas cartas como missionários, que fora a eles recomendado pelo próprio Inácio de Loyola, pela atitude mais crítica e indagativa acerca da sua validade epistêmica e científica. A esse respeito, Luce Giard (2012), ao apresentar o percurso intelectual de Michel de Certeau, salienta ter ele pertencido a uma geração de Jesuítas na França, que recebeu estímulo especial, dirigido a uma formação mais refinada de possíveis historiadores da Companhia.

[...] Na época, os superiores decidiram que, no termo da formação, os jovens mais dotados deveriam dedicar-se, temporariamente, ao estudo da história da Companhia de Jesus. Assim, na década de 1950, os Jesuítas franceses empreendiam, na esteira do que havia sido iniciado desde o final do século XIX, em Madri, - e depois transferido, em 1930, para o Institutum Historicum, em Roma - um grande trabalho de retorno às fontes da Companhia, aos textos fundadores da espiritualidade inaciana em que os primeiros jesuítas tinham encontrado o material da sua identidade e a força motriz de sua atividade por toda parte do mundo [...] (GIARD, 2012, p. 30).

Esta orientação, como vimos acima, faz parte de uma estratégia política traçada em Roma, relacionada com a história das perseguições aos jesuítas havidas em Portugal, na Espanha e na França, a partir de meados do XVIII, e que redundaram em campanhas difamatórias de larga escala e na própria extinção da Companhia de Jesus, deixando-a fragilizada por todo o século XIX e suscita nos jovens jesuítas do século XX - que viveram sob jogos republicanos, fissuras laicoreligiosas, disputas nacionais, guerras por negócios e territórios - um gosto pelos estudos sobre o seu passado, que alcançaria, sobretudo em Certeau um inesperado espectro de sofisticação interdisciplinar e metodológica, pelas questões que ele levanta e abordagens de cunho etnográfico e psicanalítico que imprime aos seus estudos, sobretudo, sobre os Jesuítas dos séculos XVI e XVII.

Em meio a inúmeras temáticas inscritas na história dos Jesuítas no Brasil, interessa-nos, por outro lado, entender o significado por eles atribuídos aos povos originários com quem estabeleceram uma relação de dominação 
civilizacional. Este é um tema bastante explorado e até bem vulgarizado por críticos da ação religiosa católica e jesuíta, que erguem com facilidade os seus tribunais de laicidade supostamente científica, ligados não raro à corrente do antijesuitismo de extração pombalina.

A esse respeito, queremos começar por perguntar se o projeto missionário de cristianização protagonizado pelos Jesuítas teve tanta eficácia assim, sabendo-se que talvez tenha sido a própria ocupação econômica e militar de territórios pelos colonos e oficiais portugueses a responsável maior pela morte e destruição desses povos. Sabe-se, porém, da estreita vinculação entre o plano de ocupação de D. João III e as atividades missionárias dos Jesuítas, convidados pelo Rei de Portugal a dele participar vivamente, na condição de cumplicidade que essa aliança representava.

\begin{abstract}
A acção evangelizadora do Catolicismo estava contemplada no Regimento como uma das suas componentes funcionais de implantação e consolidação da colonização. Separar as etnias de mais fácil assimilação de outras mais agressivas e hostis, era uma das tarefas que iriam exigir uma perfeita coordenação entre o Governo Geral e os Jesuítas. E é nesta área que a Companhia de Jesus se vai agigantar, empenhando-se na captação e catequização de crianças nativas (BARCELOS, 2013, p. 58).
\end{abstract}

Sabidamente, se essa cumplicidade entre Coroa portuguesa e Companhia de Jesus funcionou bem no instante do acordo, no correr do tempo iria mostrar os seus limites e dificuldades ao ser posto em prática, a ponto de serem os Jesuítas alvo de desconfianças, admoestações, castigos e perseguições; no caso do Brasil, estas últimas chegaram a provocar a expulsão dos padres jesuítas do seu território, em meados do século XVIII, assinada por Pombal, Ministro de D. José de Portugal. Não sendo, contudo, o nosso objetivo responder aqui a tão difícil indagação e tenso litígio, abro espaço para uma apreciação de tais ações, no século XIX, conforme foram arroladas pelo historiador J. M. de Madureira, já anunciado no começo destas notas preliminares. 
Feito isso, começaremos por analisar essa ação missionária à luz das considerações e/ou recomendações metodológicas e epistemológicas de Michel de Certeau, que funciona aqui como a interlocução necessária ao estudo de fontes históricas e do ofício do historiar, cujo alcance poderá ser medido pela enunciação que abre o primeiro tópico deste estudo. Esclarecemos que o texto aqui configurado é resultante da fusão e amadurecimento de resultados parciais apresentados e debatidos no interior de relatórios de pesquisa dirigidos ao $\mathrm{CNPq}$ e congressos da Sociedade Brasileira de História da Educação, nos últimos anos, que nos encorajaram a ampliar a sua divulgação e submissão ao debate, no âmbito da crítica histórica.

\section{A APARIÇÃO DO ESTRANGEIRO AMERICANO E DE UM “MUNDO ENCOBERTO"}

Pensamos ser necessário, antes de tudo, desnaturalizar o "encontro" entre Jesuítas e Índios. Os registros acumulados mostram ter esse encontro estabelecido uma relação de dominação que colocou os povos nativos em posição subalterna até hoje, como se fosse parte de uma linha estendida sobre o tempo de cinco séculos que nunca foi partida; e cuja eficácia terá sido tanta, que foi capaz de causar a extinção quase total das culturas e etnias que aqui estavam quando de sua chegada e do seu propósito de cristianização de incautos e culturalmente inferiores aborígenes. Vale indagar, contudo, sobre o impacto que estes nativos tiveram nas tradições e nos horizontes religiosos, culturais e civilizacionais dos padres europeus, sob a mística de serem soldados de Cristo, como se nada existisse além de suas experiências históricas restritas no espaço e no tempo em que viviam.

As questões postas por Certeau abrem novas miradas sobre tal encontro de estranhos. Ele lembra que ambos eram estrangeiros diante um do outro. E que desse estranhamento, justamente, adveio uma série de outros problemas e necessidades, a começar pela própria ideia que os europeus tinham de si próprios 
e do sentido de passado.

Desse modo, a irrupção do Novo Mundo suscitou um problema fundamental para o Ocidente porque ela quebrava uma segurança e a homogeneidade com um passado. Sob a forma de civilizações que não se referiam absolutamente ao cristianismo, de costumes sem qualquer equivalente na tradição europeia, de topografias de regiões inteiras e de mares sem qualquer correspondência nas geografias recebidas da Antiguidade, ou sob a forma de seres estranhos encontrados na América do Norte ou do Sul e tão pouco conformes aos critérios herdados da Antiguidade que havia a hesitação de qualifica-los como homens ou macacos, o problema enfrentado podia traduzir-se desta maneira: como compreender essa realidade surpreendente que fazia irrupção já não (como na nossa experiência de historiadores) sob a modalidade de um passado outro, mas sob o modo de um presente outro? De fato, a alteração produzida no presente pela emergência de um novo mundo tumultuava, também, a tradição, além de rejeitar uma parcela dessa tradição que se tornara um passado. A aparição do estrangeiro americano produzia uma clivagem na tradição e transformava regiões inteiras do "conhecido" naquilo "que deixou de ser", em regiões estrangeiras (CERTEAU, 2012, p. 169).

Tratar sob esse ângulo o processo civilizacional instalado a partir do encontro dos Jesuítas com os povos “descobertos” deixa de lado a abordagem usual de uma ação unilateral de dominação e pede o exame do impacto que cada tradição cultural teve sobre a outra. No caso do propósito ingênuo de catequização dos supostos indígenas (habitantes das Índias), imaginava que fossem estes desprovidos de valores e crenças, tecnologias e tradições de vida social plena de significado simbólico.

A leitura das famosas cartas jesuíticas oferece indicações muito firmes de que essa apregoada dominação religiosa não se deu tão facilmente, fosse por resistência cultural indígena, fosse por discordância de outros agentes colonizadores, quanto ao modo de ver e tratar códigos culturais tão distintos daqueles que os europeus traziam. Há nas descrições ali registradas mais elementos sobre dificuldades do que êxitos. Ademais, o fato de serem povos portadores de línguas distintas criava nessa comunicação um choque de entendimentos de toda espécie, que jamais foram estudadas adequadamente por 
serem as línguas indígenas imersas na oralidade de povos sem escrita. Ficou a língua do catequizador a contar e a registrar, enquanto os demais relatos se perderam no ar, levados pelo vento, pelo tempo, pela falta de tradutores à altura de tanta diversidade, ainda que os Jesuítas tenham tentado fazer esse papel, ao esculpir dicionários da língua-geral extraída do tronco tupi-guarani.

Dentro do Direito moderno, vale indagar como classificaríamos processos onde apenas um lado falasse sobre discordâncias e reivindicações. Se apenas um lado se pronuncia, o outro é silenciado, como julgar o que terá havido nesses embates e trocas culturais eivadas de mútuos preconceitos e ignorâncias? Como escrever uma narrativa histórica satisfatória, onde apenas um protagonista tem o poder e lugar de fala? Salta aos olhos que os povos indígenas falam através da fala dos jesuítas. São estes que dizem o que são aqueles com base no que deles captam e/ou ignoram. Nasce aqui um problema insolúvel de elucidação do passado, que até hoje nos deixa sem saber o que eram as sociedades humanas encontradas pelos padres europeus, no continente norte e sulamericano.

Numa passagem do documento, Chronica da Companhia de Jesus do Estado do Brasil e do que obraram seus filhos n'esta parte do novo mundo em que se trata da Entrada da Companhia de Jesus nas Partes do Brasil, editado pela primeira vez em 1663 e lido aqui na reedição de 1865, encontramos uma descrição do Brasil como "paraíso encoberto". O jesuíta questiona que apenas uma parte do mundo fosse até o século XVI conhecida:

[...] Europa, Ásia e África escolheo Deos para criar o homem, formar o paraíso terreno, (segundo opinião mais comum) authoriza-l-a com Patriarchas, cabeças dos viventes racionnaes; e o que mais he, com sua divina presença feita humana, luz verdadeira de nossa bemaventurança. Porém a outra parte da terra, outro mundo igual, não menos aprazível, da qual dissera o mesmo Criador, que era muito boa, deixou-a ficar em esquecimento, sem paraíso, sem Patriarchas, sem a sua divina presença humana, sem luz da fé, e salvação, até que depois de corridos os séculos de seis mil seiscentos e noventa e hum annos, deu ordem como aparecesse este novo, e encoberto mundo [...]. 
São registros como este que espelham, para além do relato com suas impressões do Novo Mundo, o impacto que este teve nos missionários jesuítas. Examinando o "contributo da epistolografia jesuítica”, José António Quintos Barcelos (2013), firma a importância dos dois aspectos dessa experiência de escrita.

As Cartas Jesuíticas abrem uma larga janela sobre terras, gentes e costumes que a Europa não adivinhava sequer que podiam existir. É o experimentalismo da Renascença no seu estado mais puro, devassando o desconhecido e procurando explicações, dentro das limitações do seu tempo (BARCELOS, 2013, p. 58).

Aplicando esse mesmo princípio aos povos originários da América, estes vão experimentar o espanto de ver chegar em suas terras nativas um povo estrangeiro e ameaçador que lhes criou um divisor de águas na existência e nas narrativas míticas de que dispunham sobre a sua própria origem. A partir desse encontro inesperado, surge um novo episódio e agente demolidor de suas tradições: o homem branco. A presença desse estrangeiro trouxe transtornos de toda espécie aos grupos humanos habitantes do então nascente Brasil.

\section{O PLANO POLÍTICO TRAÇADO PARA O BRASIL PELA COROA PORTUGUESA}

Sabe-se que a pedagogia jesuítica estava atrelada ao propósito político da Coroa portuguesa, desde que foram chamados por D. João III, em abril de 1540, a tomar parte na ocupação colonial. No período preparatório, coube ao Colégio das Artes de Coimbra a formação de missionários a serem enviados para o Brasil e Oriente.

O Colégio de Coimbra desempenhou um papel decisivo, numa fase inicial, na formação exclusiva de missionários jesuítas destinados ao 


\begin{abstract}
Império português, particularmente ao Oriente e ao Brasil. Nele receberam a sua preparação religiosos como Manuel da Nóbrega, Luís da Grã, José de Anchieta ou Inácio de Azevedo, tendo sido um dos primeiros a pôr em prática, com o maior entusiasmo, as novas diretrizes inacianas da instrução (SILVA, MARTINS, FERREIRA, 2008, p. 15).
\end{abstract}

O plano político de que participam os primeiros missionários jesuítas está ligado ao primeiro governador-geral do Brasil, Tomé de Souza (1549 - 1553), encarregado de aplicar o Regimento de 17 de dezembro de 1548, que trazia as balizas para a organização administrativa da colônia, com a criação da sede em Salvador, atividade missionária junto aos indígenas e da agricultura e comércio. Para José Barcelos (2013, p. 59), apoiado na visão histórica de Vitorino Nemésio, haveria "uma cumplicidade muito forte entre a gênese do Plano para o Brasil e a Companhia de Jesus", em especial, no que dizia respeito ao controle das populações nativas, com base no catolicismo dirigido sobretudo às crianças. Ao analisar esse plano, como mostra o estudo de Vitorino Nemésio (1971), salta à vista a ênfase dada à catequese dos índios como meio de ocupação e pacificação do Brasil. Em outros estudos também há forte alusão a essa aliança entre política e religião.

O trabalho efectuado pelos Jesuítas de imposição dos padrões de cultura aos índios tinha como finalidade a integração destes na sociedade colonial, evitando as revoltas e a formação de bolsas de resistência, sobretudo quando prevaleciam os costumes e tradições indígenas, nomeadamente a antropofagia e a poligamia, que tanto horrorizavam os europeus. Desta forma pensavam os padres da Companhia de Jesus proteger os índios contra os maus tratos e tentativas de escravização, continuamente efectuadas pelos colonos (SANTOS, 1996, p. 66).

Expoentes da própria historiografia portuguesa concluem ter sido danosa essa ação catequética, do ponto de vista da preservação da cultura originária do Brasil. O historiador Jorge Couto (1995) defende que a estratégia missionária de colonização teve impacto muito negativo sobre a gente brasílica, como mortes, escravização, fuga para os interiores e perda de identidade dos diversos grupos 
étnicos que habitavam o Brasil naquele período. O estudo de Ana Rita Bernardo Leitão (2005, p. 141) chama atenção para o papel do ensino de língua portuguesa para a conversão do gentio, concluindo ter sido um instrumento de poder da Coroa Portuguesa e expansão do império ultramarino, pois: "houve imposição de uma língua e de uma cultura, de modo a conduzir determinado grupo de indivíduos a uma integração num modelo civilizacional e cultural que lhe é estranho."

O processo colonial aqui tratado contém dimensões diferentes que somadas revelam a que se referia Nóbrega, quando afirmava "ser o Brasil a nossa Empresa”, ou seja, a grande missão evangelizadora de que foram incumbidos pelo Rei de Portugal. Uma mistura de propósito político e religioso que lança mão de recursos pedagógicos e artísticos nessa aproximação com os povos brasílicos, para que a ocupação e colonização tenha resultados almejados no plano da expansão portuguesa. Não seria essa uma tarefa fácil, porque a pretensão de imposição de uma cultura sobre a outra, esbarraria evidentemente nas resistências e negativas dos naturais da terra a esse estranho propósito.

São inúmeros os relatos dos jesuítas sobre o assunto, de Manoel da Nóbrega a Gabriel Mallagrida, de Jose de Anchieta a António Vieira.

A catequese iniciada sofre constante solução de continuidade. Observam uma tendência dos índios a esquecer o aprendido e a retomar seus códigos culturais de origem. O uso da arte da palavra, da música e do teatro como estratégia pedagógica vai esbarrar, não raro, na língua, na música e no complexo ritualístico indígena que têm existência e estrutura simbólica arraigada na ancestralidade tribal desses povos. 


\section{A ESCRITA EPISTOLAR E O PAPEL DA AÇÃO CATEQUÉTICA NA EXPERIMENTAÇÃO DE UMA NOVA PEDAGOGIA}

Este tópico aborda estratégias pedagógicas dos primeiros jesuítas junto aos índios do Brasil, sabendo da importância delas para a realização mais ou menos exitosa das suas missões, no interior do plano português estabelecido para expansão dos seus domínios em território americano. Tem por objetivo, primeiramente, buscar um entendimento mais atento acerca do processo educativo dirigido pelo Jesuítas; em segundo lugar, explorar a sua escrita epistolar como fonte capaz de abrir renovadas perspectivas de leitura em relação ao papel da ação catequética na experimentação de uma nova pedagogia; por fim, situar essa ação no plano político traçado pela Coroa portuguesa, no interior da historiografia disponível em acervos de Portugal. Destaca o já citado estudo de Vitorino Nemésio (1971), intitulado A Companhia de Jesus e o Plano Português do Brasil - que explora, entre outros documentos, as cartas dos primeiros jesuítas que são para cá designados como missionários, a exemplo do Padre Manuel da Nóbrega; bem como a obra de Serafim Leite (2004) sobre a história da Companhia de Jesus no Brasil.

Por meio das indicações gerais da historiografia consultada, em particular, dos dois estudiosos acima citados, fica claro que o uso da arte pelos primeiros jesuítas junto aos índios do Brasil decorre da percepção de vocação artística dos povos nativos com quem interagem, sobretudo do que observam em mulheres idosas e crianças. Ao levarem adiante esse plano pedagógico, os Jesuítas procuram combinar elementos da cultura musical europeia e indígena, combinação que terá com o tempo efeito inesperado, quando séculos depois emerge aquilo que podemos hoje chamar de música popular brasileira, somada depois à influência africana.

Nas primeiras audições, as cartas jesuíticas analisadas por Nemésio evidenciam que os missionários assistem encantados à cantoria e desempenho instrumental dos indígenas, encenados, tanto durante o dia quando são regidos 
pelos missionários, como à noite, quando levantados excitados e insones de suas redes, os índios retomam cânticos ensaiados em procissões espontâneas, que criam um efeito mágico e convertem os padres a um tipo de "apostolado coral".

Este mágico efeito observado nos Índios convertia os Padres a um tipo de "apostolado coral" que desde logo tinha suas exigências de encomenda: "Parece-me escreve Nóbrega ou alguém por ele, em nome dos meninos - "segundo eles são amigos de coisas músicas, que nós tocando e cantando entre eles ganharíamos. Pouca diferença há do que eles fazem e faríamos, se V. Ver. Nos fizesse prover de alguns instrumentos para que aqui os toquemos (enviando alguns meninos que saibam tocar), como são flautas, e gaitas e nêsperas e uns ferrinhos com umas argolinhas dentro, as quais tocam dando com um ferro no outro, e num par de pandeiros com soalhas" (NEMÉSIO, 1971, p. 248).

Entendendo serem os índios brasileiros "amigos de coisas músicas", escrevem cartas aos seus superiores da Coroa Portuguesa, pedindo o envio de mais e mais instrumentos musicais e de meninos cantores para a missão do Brasil, como estratégia política e pedagógica capaz de operar a grande conquista. No entanto, queriam os padres uma arte voltada para a catequese, a sua arma mais forte, que é tida por sua vez pelos missionários como uma espécie de arte.

O fim com que os Jesuítas foram ao Brasil foi a catequese. Assegurar, portanto, a sua eficácia e continuidade constituía a sua preocupação fundamental. Catequizar adultos? Sem dúvida. Mas era mais fácil e de resultados mais seguros conquistar e formar crianças. Com elas preparavam os homens de futuro e que, já no presente, evangelizariam os pais ou, pelo menos, captar-lhes-ia as simpatias. A instrução foi um meio "Convidamos os meninos a ler e escrever e conjuntamente lhes ensinamos a doutrina cristã, lhes prègamos para que com a mesma arte, com que o inimigo da natureza venceu o homem e, dizendo: eritissicutdiiscientesbonum et malum, com arte igual ele seja vencido, porque muito se admiram de como sabemos ler e escrever e teem muita inveja e vontade de aprender e desejam ser cristãos como nós" (LEITE, 2004, p. 15).

Segundo Serafim Leite, para além do plano meramente religioso e 
simbólico de civilidade cristã, a atividade missionária tinha, no entanto, uma feição moral e prática da luta contra a antropofagia, a superstição e a mancebia, fomentando a união e fixação dos indígenas e suas famílias de natureza volante, por meio de cerimônias, procissões e cultos e ensino de cânticos religiosos. Antes de tudo, para que a sua ação catequética alcançasse os objetivos desejados, os jesuítas começaram usando a instrução como meio de ensino, ao tempo em que tanto ensinavam sua língua, quanto aprendiam as línguas nativas. Serafim Leite extrai das cartas de Nóbrega o modo como teve início a catequese dos meninos.

[...] O meio mais seguro, e cronologicamente, o primeiro que usaram foi o da instrução, Manuel da Nóbrega, a 10 de agosto de 1549, diz que começou a visitar as Aldeias: "convidamos os meninos a ler e a escrever" [...]. O meio foi bem escolhido. Através dos filhos atingiam-se os pais, arredios, supersticiosos e, em geral, difíceis de mover, como toda a gente já feita. Inteligentes, os meninos depressa se transformavam em mestres e apóstolos. Chegando em 1550, os órfãos de Lisboa juntaramse com os meninos índios da Bahia. Alguns já sabiam as coisas da religião: com o convívio dos recém-chegados, aperfeiçoaram os seus conhecimentos; e todos juntos entraram pelas povoações pagãs, pregando, ensinando, atraindo aquelas almas a Deus (LEITE, 2004, p. 232).

Ao lado da disseminação da religião cristã em seus ritos, festas e pregações, eles se imiscuíam pouco a pouco na vida dos indígenas para entender a organização de atividades agropastoris e procuravam tanto aprender, quanto mudar seus valores e costumes, ação que envolve um confronto muito vivo de línguas e códigos culturais.

Por essa razão, foram diversos os livros e catecismos escritos em língua nativa para viabilizar a doutrinação cristã desejada, entre os quais podemos citar alguns, encontrados no acervo da Biblioteca Nacional de Lisboa: 1) Vocabulario da Lingoa Brasilica [Manuscrito] / Leonardo do Vale (publicado no v. XX da Colecção do Departamento de Cultura, S.P., 1938), coordenado e prefaciado por Plínio Airosa, segundo cópia feita em Piratininga, 1621; 2) Catecismo Brasilico da Doutrina Cristã: com o Ceremonial dos Sacramentos, \& mais actos 
Parochiaes / composto por Padres Doutos da Companhia de Jesus, aperfeiçoado, \& dado a luz pelo Padre Bertholomeu de Leam da mesma Companhia, publicado em Lisboa, na Officina de Miguel Deslandes, em 1686; 3) O Catecismo da Doutrina Christã na Língua Brasílica da Nação Kiriri / composto pelo P. Luis Vincencio Mamiani da Companhia de Jesus, missionário da Província do Brasil, publicado em Lisboa, na Officina de Miguel Deslandes, impressor de sua Magestade, em 1698; 4) A Arte da Grammatica da Língua do Brasil / composto pelo P. Luiz Figueira, natural de Almodovar, publicado em quarta impressão em Lisboa, na Officina Patriarcal, em 1795.

Parece, contudo, que a estratégia inicial esbarrou em dificuldades que precisaram ser contornadas, por meio de uma pedagogia mais atraente, qual seja ligada às outras artes, que vão além da palavra. Nessa busca, se a percepção da música como meio de comunicação catequética ocupa a atenção de Manoel da Nóbrega, será o teatro a forma encontrada por José de Anchieta para aproximarse dos indígenas do Brasil.

As cartas dos jesuítas compõem um conjunto de registros que configuram uma escrita epistolar considerada de grande importância por conter os registros feitos por eles em suas andanças e ações missionárias por onde passaram, os quais foram conservados em acervo próprio da Companhia de Jesus em Roma até hoje, servindo de fonte histórica muito requisitada para os estudiosos de todo o mundo. Tamanho zelo por esse registro tem explicação não apenas no controle e regulamento interno da Companhia de Jesus, mas também no compromisso político assumido por ela junto à Coroa portuguesa, sob o comando inicial de $\mathrm{D}$. João III.

As narrativas dos Padres Manoel da Nóbrega e Jose de Anchieta são fontes primordiais para o estudo das estratégias utilizadas pelos primeiros jesuítas missionários chegados ao Brasil para a sua aproximação dos povos originários. Há trechos delas que mostram o modo como chegou Nóbrega, por exemplo, ao uso da música como instrumento pedagógico e de catequese das crianças indígenas e mulheres idosas. Ele percebeu o quanto elas se sentiam 
atraídas pelos sons musicais que eles próprios extraíam dos seus instrumentos. A partir disso, entende que teriam os índios vocação para a música e escreve aos seus superiores pedindo o envio de instrumentos europeus para adequar esse gosto ao estilo que considera mais certo e sublime. Vale a pena ler a respeito o registro feito por Nóbrega, ao chegar à Bahia com a comitiva de Tomé de Sousa, em 1549, em comentário inspirador do historiador açoriano.

\begin{abstract}
O ambiente de milagre, a cruz ao alto, as capelas de flores toucando os colomins, tudo exaltava as tabas e incitava ao festim: os "meninos cantaram e folgaram muito, e de noite levantavam-se ao modo deles e cantaram e tocaram com taquaras, que são umas canas grossas com que dão no chão e com o som que fazem cantam, e com maracas, que são de umas frutas uns cascos como cocos, e furados, com uns paus, por onde deitam pedrinhas dentro, o qual tocam. E logo os meninos cantando de noite (como é costume dos negros) se levantavam das suas redes (são leitos em que eles dormem) e andavam espantados atrás de nós" (NEMÉSIO, 1971, p. 247).
\end{abstract}

O estudo de Vitorino Nemésio (1971) sobre a relação entre as missões jesuíticas e o plano português para o Brasil salienta que os padres jesuítas se deixaram encantar pelas práticas musicais dos povos brasílicos, desde os primeiros contatos, aspecto que inspirou a pedagogia adotada por eles para realizar sua catequese missionária. $\mathrm{O}$ oposto também se deu, na medida em que a referida pedagogia ia sendo utilizada, quando os meninos se aproximam dos padres para com eles aprender a música que trazem.

E quando os meninos vão tocando e cantado pelas suas aldeias, vêm os velhos (que costumam ter medo de nós e escondem os filhos) a bailar sem descansar, e até mesmo as velhas (esta era a grande conquista), "por cujo conselho se regem assim velhos como moços. E os meninos (colomins) "andam a trás de nós, esperando quando havemos de tocar ou cantar", pedindo-nos que os ensinemos, e dizendo-nos alguns, que querem vir conosco e assim o desejam, mas não ousam fiar-se de todo, pelos enganos e males que até aqui receberam dos cristãos passados" (Idem, p. 249). 
Isto significa que há um confronto cultural ou jogo de influências mútuas, que vai modelando uma estratégia pedagógica híbrida, um modo de atuar dos padres junto aos indígenas. Um aspecto curioso a destacar, se refere às restrições postas ao uso da música pela Companhia de Jesus, desde a sua fundação. A mudança de atitude se dá em função do contato dos Jesuítas com povos do Oriente e da América. O estudo de Marcos Holler (2010) aborda essa questão de modo bem elucidativo.

\begin{abstract}
Nas missões da Índia, antes da chegada do padre Nóbrega ao Brasil, os missionários conheciam o efeito que a música exercia sobre o gentio e, apesar das restrições nos regulamentos, o uso do canto e de instrumentos foi intenso nas aldeias do Brasil colonial, e a introdução de elementos musicais europeus pelos jesuítas influenciou aspectos da formação de culturas regionais que se mantêm até hoje. Fora das aldeias, entretanto, os padres jesuítas da América Portuguesa seguiram os preceitos da ordem e evitaram a prática musical nos seus estabelecimentos. Nos colégios e seminários havia prática musical, realizada geralmente por externos) membros de outras ordens, músicos contratados ou estudantes seminaristas) e em determinadas ocasiões (HOLLER, 2010, p. 220).
\end{abstract}

A ideia de usar a música como meio de aproximação com os indígenas ocorreu a Nóbrega, ao observar que eles não só tinham seus próprios instrumentos musicais, como cantavam e dançavam acompanhados dos sons ritmados de suas taquaras e maracas. No entanto, o jesuíta sugere que esses instrumentos sejam substituídos por flautas, gaitas e nêsperas, pois considera que tem algo de satânico nos sons extraídos dos instrumentos que chama de selvagens, podendo ser substituídos na sua opinião pela suavidade harmônica da música europeia, como mostra Nemésio, através de outro trecho da carta de Anchieta: "Os embelecos satânicos da selva, batidos a taquara e a maracá suplantados pelas harmonias divinas portuguêsmente soadas ao fôlego da gaita céltica, ao tinir dos ferrinhos e ao arábico tum-tum do pandeiro de soalhas [...]" (Idem, p. 248).

Por essa razão, com o passar do tempo e da organização das aldeias pelos 
missionários, em quase tudo estaria presente a música a animar e conquistar corpos e almas indígenas de forma lúdica e sedutora, para honra e glória dos seus senhores, no céu e na terra. Em trecho de carta de Manoel da Nóbrega, citado por Serafim Leite (2004), há uma descrição de procissão que merece ser destacada, por ocasião da Semana Santa, em 1559, na aldeia de São Paulo, onde há cantoria dos indígenas nas duas línguas.

\footnotetext{
Fizemos procissão solene, porque veio folia da cidade [...] - iam os meninos cantando, na língua e em português, cantigas a seu modo, dando glória a Nosso Senhor; e foram todos os Índios em procissão, assim homens e mulheres, tendo as ruas limpas e bem enramadas, de que muito se alegrou meu espírito em o Senhor (NÓBREGA apud LEITE, 2004, p. 13).
}

Desse modo, os Jesuítas se mostram empenhados na ação catequética e veem nas artes - uma associação de recursos extraídos da língua, da música e do teatro - as suas mais fortes aliadas. São tentativas e práticas marcantes dessa ação missionária, que são aludidas até hoje, quando se quer caracterizar a pedagogia desses missionários, muito embora seja impossível mensurar o seu alcance e/ou êxito.

\section{O RETORNO DOS JESUÍTAS AO BRASIL NO SÉCULO XIX: MISSÕES RURAIS E CITADINAS, CATEQUESE INDÍGENA E FUNDAÇÃO DE COLÉGIOS}

Se os séculos XVI e XVII são considerados o período áureo das missões jesuíticas, o século XVIII lhes trará inúmeras dificuldades e atropelos. Já o século XIX será de negociações e retornos, com vistas à recuperação do direito e liberdade de ação educativa dos Jesuítas na Europa e em diferentes partes do mundo. Os Jesuítas de várias províncias começam a voltar ao Brasil, envolvendo padres portugueses, espanhóis, italianos e alemães. 
Se exceptuarmos, entre os adversários, os mais sectários, que só sabem ler pelas envenenadas cartilhas pombalinas, somos forçados a confessar que mesmo entre os mais acirrados inimigos dos Jesuitas lhes fazem a mais completa justiça, lhes rendem o mais justo e valioso preito de insuspeita homenagem, pelos serviços presados pela Companhia à Colonização, formação da nacionalidade, catequese, instrucção e educação dos primeiros brasileiros.

Egual justiça, porém, não se faz, em geral, aos Jesuítas que, depois do restabelecimento da Companhia, voltaram ao Brail, já independente, em 1841, e n'elle trabalharam e trabalham, há já mais de 80 anos; para com o qual, não menos que os antigos jesuítas seus irmãos, grangearam indiscutivelmente os mais justos títulos de benemerências (MADUREIRA, 1924, p. 05).

$\mathrm{O}$ autor se queixa logo a seguir devido a inexistência de uma história da Companhia de Jesus no Brasil colonial e independente, razão pela qual ele próprio oferece dados para recompor a memória histórica do trabalho missionário dos Jesuítas portugueses em solo brasileiro no século XIX, quando inclusive estiveram impedidos de existir em Portugal até 1829, em face da segunda expulsão por eles vivenciadas no País, por ocasião da instalação na Monarquia Constitucional, que demarcaria o fim do absolutismo no reino português.

O historiador jesuíta lembra que pairava sobre os missionários a vigência das leis e notícias difamatórias de extração pombalina, o que lhes provocava receio de novas perseguições e muita precaução.

Voltaram os Padres para o Brasil independente, no qual, entretanto, se dizia - anachronicamente - estarem ainda em vigor as leis pombalinas de Portugal sobre a expulsão e exílio dos Jesuítas. Entraram, pois com medo e, nos princípios obrigados a se manterem na penumbra, afim de não exasperar e excitar os ódios dos exaltados e não prejudicar a obra de Deus na salvação das almas. Assim mesmo, começaram logo a agir, entregando-se a innumeras missões rurais nas villas e povoados e depois nas cidades de Santa Catarina e do Rio Grande do Sul [...] (MADUREIRA, 1924, p. 22).

As missões interioranas estavam relacionadas com pregações e 
sacramentos, como batismos e casamentos, para operar a regularização da condição cristã de fiéis dentro dos critérios instituídos pelo catolicismo romano. A esta ação foi sendo somada a tentativa de retomada da catequização de grupos indígenas, entre as regiões sul e central do Brasil, assim como a abertura de colégios para oferecer formação jesuítica à juventude brasileira de elite.

A crônica de Madureira refere-se ao intento de restabelecimento das missões guaranis, em meados do século XIX, no que os Jesuítas teriam sido derrotados, segundo ele, por força da interferência da Maçonaria. Outra força bastante hostil a esse propósito teria sido a disputa por terras indígenas por pessoas ambiciosas, acusando os Jesuítas por defenderem direitos dos índios de ocupação. Refere-se a lutas na Câmara de Deputados e decisão do governo de passar as reduções para os Padres Capuchinhos. A cronologia oferecida pelo autor em foco acerca das ações jesuítas no Brasil do século XIX, entre 1841 e 1873, permite-nos vislumbrar a diversidade de instituições educativas criadas pela Companhia de Jesus naquele período de construção nacional. Em 1867, fundam o Colégio São Francisco Xavier e abrem o Colégio de São Luiz do Ytú, em São Paulo. No ano de 1870, cria-se uma escola que virá a ser depois o Ginásio de Conceição, em São Leopoldo, educando centenas de alunos e dando lugar décadas depois, em 1913, ao Seminário Provincial. Em 1886, dá-se a fundação do Colégio Anchieta, em Nova Friburgo. Em 1893, é criado o Externato e Semi-Internato Santo Inácio, no Rio de Janeiro; 1890, Gymnasio Anchieta de Porto Alegre, 1895, Gymnasio Gonzaga (Pelotas), em 1899, o Collegio do Sagrado Coração, no Rio Grande. Em Pernambuco, os Jesuítas enfrentaram processo advindo de disputas com a Maçonaria, que ficou cunhada de Questão Religiosa de 1873, situação que acaba por gerar uma nova expulsão dos Jesuítas do nordeste brasileiro.

\section{CONSIDERAÇÕES FINAIS}

Estamos diante de fontes produzidas por intelectuais jesuítas, que nos dão notícia de suas ações no Brasil, no decorrer do século XVI e do XIX. Estão 
assim elas tão distanciadas no tempo e mesmo assim permanecem próximas em relação ao ideário que as anima. A narrativa sobre o retorno dos Jesuítas no século dezenove traz indicações raras e, por isso mesmo, valiosas da persistência dessa ação missionária e educativa em contexto internacional e nacional de hostilidade aos Jesuítas, espírito que paira sobre a Companhia de Jesus como uma marca das perseguições sofridas esse o século XVIII.

É interessante observar que os Jesuítas em questão são de várias nacionalidades, por serem deslocados da Itália, Espanha, Portugal e Alemanha para ocupar o lugar de missionários católicos no Brasil, onde estiveram radicados antes por mais de dois séculos. Os Jesuítas voltam para resgatar espaços perdidos. Continuam a pensar na importância de catequizar os índios do Brasil para resgatar missões interrompidas, estabelecer instituições de ensino mais sólidas e duradouras voltadas à educação de uma elite letrada e católica militante.

Isto significa que ainda há no século XIX grupos indígenas espalhados pelos interiores do Brasil a quem os Jesuítas desejam sempre ainda inocular a fé cristã. Entendemos assim que as missões do período colonial, ao serem extintas por Pombal, deixaram de atuar sobre essa população, mas dela não se esqueceram os Jesuítas, justamente porque a atividade missionária permaneceu viva, sendo vistas como experiências de um tempo de encantamento com aquele imenso mundo novo que estivera por milhares de anos encoberto dos europeus, vivendo os povos que o habitavam de uma forma culturalmente distinta e alheia, tanto à economia mercantil, quanto à religião católica.

Voltando aos ensinamentos de Certeau, tratava-se de um encontro de estranhos. Que, aliás, até hoje são sujeitos históricos muito apartados e diferentes um do outro, em especial, quando se examina os grupos indígenas sobreviventes. Inclusive no tocante às narrativas de suas fundações. Os povos indígenas guardam, em meio aos seus relatos míticos, aquele que reporta a chegada dos povos europeus como uma grande catástrofe. Já os missionários jesuítas cultuam em sua memória histórica epistolar um passado de descobertas espantosas e tentativas de dominação cultural e religiosa, que jamais foram assimiladas pelos 
povos nativos, como parte autêntica do seu imaginário. Tais tentativas ficaram até hoje como memória infeliz de um acontecimento que lhes ameaçou, a ponto de destruir o paraíso encoberto a que se referiram os jesuítas europeus do século XVI, onde viveram inocentes, sem o peso do pecado, nem da culpa, entre deuses poderosos que representam as forças da própria natureza exuberante que lhes nutria corpo e alma.

\section{REFERÊNCIAS}

BARCELOS, José António Quintos. A Companhia de Jesus e o Brasil na segunda metade do século XVI e a visão histórica de Vitorino Nemésio. Porto: Papiro Editora, 2013. 181 p.

CERTEAU, Michel de. História e psicanálise: entre a ciência e ficção. 2. ed., Belo Horizonte: Autêntica Editora, 2012, 254 p.

COUTO, Jorge. A construção do Brasil. Lisboa: Edições Cosmos, 1995.

GIARD, Luce. Um caminho não traçado. In: CERTEAU, Michel de. História e psicanálise: entre a ciência e ficção. 2. ed., Belo Horizonte: Autêntica Editora, 2012, p. 07-41.

HOLLER, Marcos. Os Jesuítas e a música no Brasil colonial. Campinas/SP: Editora da Unicamp, 2010.

LEITE, Serafim. História da Companhia de Jesus no Brasil. Organização César Augusto dos Santos et al. São Paulo: Edições Loyola, 2004. 4 v.

LEITÃO, Ana Rita Bernardo. Da selva para a escola: alfabetização dos índios do Brasil pela Companhia de Jesus (século XVI) - Um contributo para a história da didactica do Português como língua não-materna. 2005. Dissertação (Mestrado em Língua e Cultura Portuguesa) - Faculdade de Letras, Universidade de Lisboa, Lisboa, 2005.

NÓBREGA, Padre Manoel da. Cartas do Brasil e mais escritos. Introdução e Selecção de João Alves das Neves. Lisboa: Universitária Editora, 2004. $15^{8}$ p.

MADUREIRA, J. M. de (S.J.). A Companhia de Jesus e o Brasil (15491759) (1841-1924). Rio de Janeiro: Imprensa do Annuario do Brasil - Almanak Laemmert, Separata do Annuario Catholico, 1924. 
NEMÉSIO, Vitorino. O campo de São Paulo. A Companhia de Jesus e o plano português do Brasil. 3. ed. Lisboa: Secretaria de Estado da Informação e do Turismo/ Edições Panorama, 1971. 417 p.

SANTOS, Dulce Maria Colmonero dos. Índios e Jesuítas no Brasil Quinhentista. 1996. 187 p. Dissertação (Mestrado em História IberoAmericana) - Universidade Portucalense - Infante D. Henrique, Porto, 1996.

SILVA, Ana Cristina; MARTINS, Lígia; FERREIRA, Teresa Duarte. Os manuscritos da Aula da Esfera - dúvidas e incertezas. In: Catálogo SphaeraMundi / A Ciência na Aula da Esfera. Manuscritos Científicos do Colégio de Santo Antão nas Colleções BNP. Lisboa: Biblioteca Nacional de Portugal, 2008. p. 11-25. 347 p.

VASCONCELOS, Simão de. Chronica da Companhia de Jesus do estado do Brasil e do que obraram seus filhos n'esta parte do novo mundo em que se trata da entrada da Companhia de Jesus nas partes do Brasil, 1. ed., 1663. Lisboa: Typ. do Panorama, 1865. 